\title{
Virus-induced dysfunction of CD4+CD25+ T cells in patients with HTLV-I-associated neuroimmunological disease
}

\author{
Yoshihisa Yamano, ${ }^{1,2}$ Norihiro Takenouchi, ${ }^{1}$ Hong-Chuan Li, ${ }^{3}$ Utano Tomaru, ${ }^{1,4}$ Karen Yao, ${ }^{1}$ \\ Christian W. Grant, ${ }^{1}$ Dragan A. Maric, ${ }^{5}$ and Steven Jacobson ${ }^{1}$ \\ 1Viral Immunology Section, Neuroimmunology Branch, National Institute of Neurological Disorders and Stroke, NIH, Bethesda, Maryland, USA. \\ ${ }^{2}$ Kagoshima City Hospital, Kagoshima, Japan. ${ }^{3}$ Viral Epidemiology Branch, Division of Cancer Epidemiology and Genetics, National Cancer Institute, \\ Bethesda, Maryland, USA. ${ }^{4}$ Department of Pathology/Pathophysiology, Hokkaido University Graduate School of Medicine, Sapporo, Japan. \\ ${ }^{5}$ Laboratory of Neurophysiology, National Institute of Neurological Disorders and Stroke, NIH, Bethesda, Maryland, USA.
}

\begin{abstract}
$\mathrm{CD}^{+} \mathrm{CD}^{+} 5^{+}$Tregs are important in the maintenance of immunological self tolerance and in the prevention of autoimmune diseases. As the $\mathrm{CD}^{+} \mathrm{CD}^{2} 5^{+} \mathrm{T}$ cell population in patients with human $\mathrm{T}$ cell lymphotropic virus type I-associated (HTLV-I-associated) myelopathy/tropical spastic paraparesis (HAM/TSP) has been shown to be a major reservoir for this virus, it was of interest to determine whether the frequency and function of $\mathrm{CD}^{+} \mathrm{CD}^{2} 5^{+}$Tregs in HAM/TSP patients might be affected. In these cells, both $\mathrm{mRNA}$ and protein expression of the forkhead transcription factor Foxp3, a specific marker of Tregs, were lower than those in $\mathrm{CD}^{+} \mathrm{CD}^{2} 5^{+} \mathrm{T}$ cells from healthy individuals. The virus-encoded transactivating HTLV-I tax gene was demonstrated to have a direct inhibitory effect on Foxp3 expression and function of $\mathrm{CD}^{+} \mathrm{CD} 25^{+} \mathrm{T}$ cells. This is the first report to our knowledge demonstrating the role of a specific viral gene product (HTLV-I Tax) on the expression of genes associated with Tregs (in particular, foxp 3 ) resulting in inhibition of Treg function. These results suggest that direct human retroviral infection of $\mathrm{CD}^{+} \mathrm{CD}^{2} 5^{+} \mathrm{T}$ cells may be associated with the pathogenesis of HTLV-Iassociated neurologic disease.
\end{abstract}

\section{Introduction}

The human T cell lymphotropic virus type I (HTLV-I) is an exogenous human retrovirus that is associated with chronic, persistent infection of human T cells. While the majority of infected individuals remain healthy, lifelong asymptomatic carriers, approximately $2-3 \%$ develop an aggressive mature $\mathrm{T}$ cell malignancy termed adult $\mathrm{T}$ cell leukemia, and another $0.25-3 \%$ develop an inflammatory disease of the CNS termed HTLV-I-associated myelopathy/tropical spastic paraparesis (HAM/TSP) (1-3). Furthermore, in some HAM/TSP patients, other autoimmune diseases characterized by multiorgan lymphocytic infiltrates, including uveitis, arthritis, polymyositis, Sjögren syndrome, atopic dermatitis, and alveolitis, have been reported $(4,5)$. Patients with HAM/TSP have high frequencies of HTLV-I-infected T cells and heightened virusspecific immune responses, including increased proinflammatory cytokine production (6-8). One of the most striking features of the cellular immune response in HAM/TSP patients is the increased numbers of HTLV-I-specific CTLs, which are lower or absent in asymptomatic carriers (9). In some HLA-A*201 HAM/ TSP patients, the frequency of Tax11-19-specific CTLs can be as high as $30 \%$ of total CD8 ${ }^{+} \mathrm{T}$ cells in peripheral blood (10) and even higher in cerebrospinal fluid (6). Neuropathological findings have demonstrated focal infiltrates of $\mathrm{T}$ cells and macrophages in the CNS (11). These observations have suggested that inflammatory

Nonstandard abbreviations used: AC, HTLV-I-infected asymptomatic carrier; GITR, glucocorticoid-induced TNF receptor family-related; HAM/TSP, HTLV-Iassociated myelopathy/tropical spastic paraparesis; HD, healthy donor; HTLV-I, human T cell lymphotropic virus type I.

Conflict of interest: The authors have declared that no conflict of interest exists.

Citation for this article: J. Clin. Invest. 115:1361-1368 (2005).

doi:10.1172/JCI200523913
T cells (particularly virus-specific $\mathrm{CD}^{+} \mathrm{CTLs}$ ) may play an immunopathologic role in this disorder.

Recently, a large body of information has demonstrated that $\mathrm{CD}^{+}$Tregs constitute an important component of the normal, healthy immune response. These cells are engaged in the maintenance of immunologic self tolerance by actively suppressing the activation and expansion of self-reactive lymphocytes that may cause autoimmune disease $(12,13)$. The majority of these Tregs constitutively express CD25 (the IL-2 receptor $\alpha$ chain). The normal CD $4{ }^{+} \mathrm{CD} 25^{+}$Treg population constitutes $5-10 \%$ of peripheral $\mathrm{CD}^{+} \mathrm{T}$ cells in mice and $1-2 \%$ in humans (only the $\mathrm{CD} 4^{+} \mathrm{CD} 25^{\text {high }}$ $\mathrm{T}$ cells exhibit similar regulatory function in humans) (14). Removal or functional alteration of this population from normal rodents leads to the spontaneous development of various autoimmune diseases $(12,13)$. $\mathrm{CD} 4{ }^{+} \mathrm{CD} 25^{+}$Tregs have unique immunological characteristics. For example, they do not proliferate in response to antigenic stimulation in vitro and can potently suppress the proliferation of other $\mathrm{CD} 4^{+}$or $\mathrm{CD}^{+} \mathrm{T}$ cells induced either by polyclonal or antigen-specific stimuli $(12,13)$. Costimulation with anti-CD28 or provision of exogenous IL-2 inhibits the suppressive ability of these $\mathrm{CD}^{+} \mathrm{CD} 25^{+}$Tregs $(15,16)$. They constitutively express gene products of glucocorticoid-induced TNF receptor family-related (GITR) receptors and cytotoxic T lymphocyte-associated antigen 4 (CTLA-4) (17-21). Furthermore, it has been reported that forkhead transcription factor (foxp3) gene is specifically expressed in Tregs and is required for their development and function (22-24). Interestingly, mice of the foxp3 mutant strain, or scurfy mice, succumb to a $\mathrm{CD}^{+} \mathrm{T}$ cell-mediated, lymphoproliferative, and autoimmune disease characterized by multiorgan lymphocytic infiltrates and overproduction of proinflammatory cytokines (25-27). Furthermore, similar immunological abnormalities are observed in CTLA-4-defi- 
A

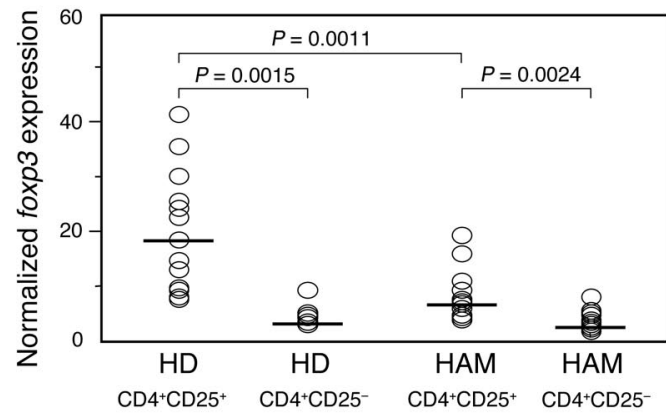

B
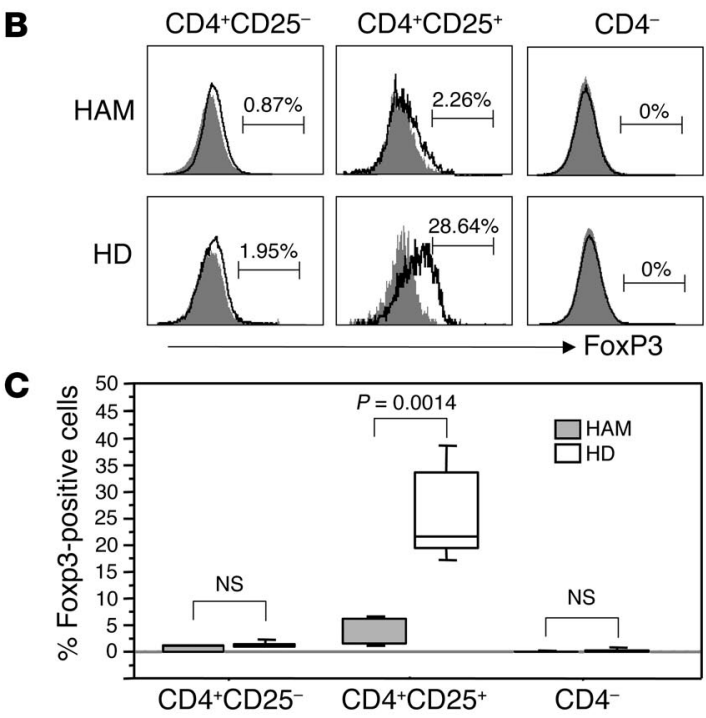

cient mice $(28,29)$. HAM/TSP patients share many immunological characteristics with the scurfy foxp 3 mutants and CTLA-4-deficient mice, including the in vitro spontaneous lymphoproliferation of predominantly $\mathrm{CD} 4^{+} \mathrm{T}$ cells and clinical manifestations associated with autoimmune disease characterized by multiorgan lymphocytic infiltrates and overproduction of proinflammatory cytokines. It was therefore of interest to determine the frequency and function of $\mathrm{CD}^{+}{ }^{+}$Tregs in patients with HAM/TSP.

We have recently demonstrated that in HAM/TSP patients, the $\mathrm{CD} 4{ }^{+} \mathrm{CD} 25^{+} \mathrm{T}$ cell population is the main reservoir for HTLV-I: more than $90 \%$ of these cells contain HTLV-I proviral DNA, and they express HTLV-I tax mRNA at significantly higher levels than in $\mathrm{CD}^{+}{ }^{+} \mathrm{CD} 25^{-}$cells (30). Moreover, these HTLV-I-infected $\mathrm{CD} 4^{+} \mathrm{CD} 25^{+} \mathrm{T}$ cells were not functionally suppressive but rather were shown to be stimulatory for the HTLV-I Tax-specific proliferation of $\mathrm{CD}^{+} \mathrm{T}$ cells (30). Therefore, we have hypothesized that HTLV-I infection of $\mathrm{CD} 4^{+} \mathrm{CD} 25^{+} \mathrm{T}$ cells may alter the regulatory function of this population of $\mathrm{CD} 4^{+}$cells or that the proportion of Tregs may be decreased in HAM/TSP patients. To answer these questions, we developed a quantitative TaqMan PCR assay for the detection of human foxp3 mRNA and a FACS assay for the detection of Foxp3 protein. We have shown that foxp3 mRNA expression in $\mathrm{CD} 4^{+} \mathrm{CD} 25^{+} \mathrm{T}$ cells of HAM/TSP patients is lower than that of HDs. In addition, $\mathrm{CD} 4^{+} \mathrm{CD} 25^{+} \mathrm{T}$ cells of HAM/TSP patients have lower levels of expression of Foxp3 protein as well as other Treg markers such as CTLA-4 and GITR but were overproducing proinflammatory cytokines such as IL-2 that are known to inhibit $\mathrm{CD} 4{ }^{+} \mathrm{CD} 25^{+}$regulatory activity. Importantly, we have

\section{Figure 1}

Decreased Foxp3 expression in $\mathrm{CD} 4{ }^{+} \mathrm{CD} 25^{+} \mathrm{T}$ cells from HAM/TSP patients. (A) Quantitative expression of foxp3 mRNA was determined by real-time RT-PCR. The level of foxp3 mRNA expression was calculated as the relative quantity of foxp3 mRNA expression divided by the relative quantity of endogenous control HPRT mRNA expression, as described in Methods. The data represent isolated cell subsets $\left(\mathrm{CD} 4^{+} \mathrm{CD} 25^{+}\right.$or $\left.\mathrm{CD} 4^{+} \mathrm{CD} 25^{-}\right)$from 13 uninfected HDs and 13 HAM/TSP patients (HAM). Foxp3 mRNA expression was significantly reduced in the $\mathrm{CD} 4{ }^{+} \mathrm{CD} 25^{+} \mathrm{T}$ cell subset from HDs compared with that from HAM/TSP patients. (B) A representative histogram of intracellular expression of Foxp3 protein showing results from flow cytometric analysis of PBMC samples from HAM/TSP patients and HDs. Foxp3 protein expression was detected in the $\mathrm{CD} 4^{+} \mathrm{CD} 25^{+} \mathrm{T}$ cell subset from HDs but not in $\mathrm{CD}^{+}{ }^{+} \mathrm{CD} 25^{-}$or in total CD4- $\mathrm{T}$ cell subsets. In contrast, the number of Foxp3-positive cells in CD4+CD25+ $\mathrm{T}$ cells from HAM/TSP patients was clearly reduced. (C) Data represent averaged percentage of Foxp3-positive cells in each $\mathrm{T}$ cell subset. The percentage (mean \pm SD) of Foxp3-positive cells in CD4 ${ }^{+} \mathrm{CD} 25^{+} \mathrm{T}$ cells of $8 \mathrm{HAM} / \mathrm{TSP}$ patients $(3.09 \% \pm 1.04 \%)$ was significantly lower than that of $8 \mathrm{HDs}(25.9 \% \pm 8.23 \% ; P=0.0014)$. No difference in the protein expression levels of Foxp3 was observed in $\mathrm{CD}^{+}{ }^{+} \mathrm{CD} 25^{-}$or CD4- cells between HAM/TSP patients and HDs.

also demonstrated defects in the regulatory function of HTLV-I tax gene-transfected $\mathrm{CD} 4^{+} \mathrm{CD} 25^{+} \mathrm{T}$ cells. In an attempt to define which HTLV-I virus gene(s) may be associated with the dysregulation of Foxp3, we have transfected the HTLV-I-transactivating tax gene into $\mathrm{CD} 4{ }^{+} \mathrm{CD} 25^{+} \mathrm{T}$ cells from HDs and have demonstrated a Tax-specific inhibition of foxp 3 expression that can suppress $\mathrm{CD} 4{ }^{+} \mathrm{CD} 25^{+}$Treg function. Collectively, these results demonstrate that a consequence of HTLV-I infection of $\mathrm{CD} 4^{+} \mathrm{CD} 25^{+} \mathrm{T}$ cells in HAM/TSP patients (30) is the suppression in both the frequency and function of $\mathrm{CD} 4^{+}$Tregs, which may be associated with a break in immunological self tolerance resulting in the HTLV-I-associated disorders with multiorgan lymphocytic infiltrates.

\section{Results}

Decreased foxp 3 expression in $\mathrm{CD}^{+} \mathrm{CD} 25^{+} \mathrm{T}$ cells from HAM/TSP patients. To assess whether $\mathrm{CD} 4^{+} \mathrm{CD} 25^{+}$cells in HAM/TSP patients have altered expression of Foxp 3 , we isolated $\mathrm{CD}^{+} \mathrm{CD} 25^{+}$and $\mathrm{CD} 4^{+} \mathrm{CD} 25^{-} \mathrm{T}$ cells from PBMCs of HAM/TSP patients, HTLV-Iinfected asymptomatic carriers (ACs), and uninfected healthy donors (HDs) and quantified the expression levels of foxp 3 by real-time RT-PCR. The percentages (mean $\pm \mathrm{SD}$ ) of $\mathrm{CD} 4^{+} \mathrm{CD} 25^{\text {high }}$ $\mathrm{T}$ cells in PBMCs of HAM/TSP patients, ACs, and HDs were $19.52 \% \pm 9.00 \%, 5.30 \% \pm 1.62 \%$, and $2.19 \% \pm 1.07 \%$, respectively (Supplemental Figure 1; supplemental material available online with this article; doi:10.1172/JCI200523913DS1). As expected, foxp 3 mRNA expression levels were significantly higher $(P=0.0015)$ in $\mathrm{CD}^{+} \mathrm{CD} 25^{+}$cells compared with $\mathrm{CD} 4^{+} \mathrm{CD} 25^{-}$cells from $13 \mathrm{HDs}$ (Figure 1A). Similarly, foxp 3 expression levels were also higher in $\mathrm{CD} 4^{+} \mathrm{CD} 25^{+}$cells compared with $\mathrm{CD} 4^{+} \mathrm{CD} 25^{-} \mathrm{T}$ cells from $13 \mathrm{HAM} / \mathrm{TSP}$ patients $(P=0.0024)$. However, the expression of foxp 3 in the $\mathrm{HAM} / \mathrm{TSP} \mathrm{CD} 4^{+} \mathrm{CD} 25^{+}$population (6.81 \pm 4.77 ; see Methods) was significantly lower (approximately 2.5-fold; $P=0.0011$ ) than that observed in $\mathrm{HD} \mathrm{CD} 4^{+} \mathrm{CD} 25^{+}$cells (16.01 \pm 10.76 ; see Methods) (Figure 1A). foxp 3 expression levels in $\mathrm{CD} 4{ }^{+} \mathrm{CD} 25^{+}$cells from $2 \mathrm{ACs}$ were comparable to levels observed in cells from HDs (Table 1). No difference in the expression levels of foxp 3 mRNA was observed among HAM/TSP, AC, and HD 
Table 1

foxp3 mRNA expression in CD4+CD25+ $T$ cells and CD4+CD25-

T cells from HAM/TSP patients, ACs, and HDs

\begin{tabular}{lcccccc} 
& \multicolumn{2}{c}{ HDs $^{\mathrm{A}}$} & \multicolumn{2}{c}{ ACs $^{\mathrm{B}}$} & \multicolumn{2}{c}{ HAM $^{\mathrm{A}}$} \\
& Mean & SD & Mean & SD & Mean & SD \\
$\mathrm{CD}^{+}{ }^{+} \mathrm{CD} 25^{+}$ & 16.01 & 10.76 & 13.62 & 0.17 & 6.81 & 4.77 \\
$\mathrm{CD}^{+}{ }^{+} \mathrm{CD} 25^{-}$ & 2.61 & 1.62 & 3.73 & 0.30 & 2.48 & 1.74 \\
\hline
\end{tabular}

Data represent normalized foxp3 mRNA expression. HAM, HAM/TSP patients. ${ }^{A} n=13 .{ }^{B} n=2$.

$\mathrm{CD} 4^{+} \mathrm{CD} 25^{-}$cells. These results are in agreement with previous studies of both mouse and human $(22,31)$ Tregs demonstrating that the transcription factor Foxp3 is preferentially expressed in $\mathrm{CD} 4^{+} \mathrm{CD} 25^{+} \mathrm{T}$ cells. However, the foxp 3 expression was reduced in $\mathrm{CD} 4^{+} \mathrm{CD} 25^{+} \mathrm{T}$ cells from patients with HAM/TSP.

Loss of foxp 3 protein expression on $\mathrm{CD} 4^{+} \mathrm{CD} 25^{+}$T cells from $\mathrm{HAM} / \mathrm{TSP}$ patients. As we had shown that the level of foxp $3 \mathrm{mRNA}$ was significantly decreased in $\mathrm{CD} 4^{+} \mathrm{CD} 25^{+} \mathrm{T}$ cells from HAM/TSP patients compared with HDs, we wished to determine whether comparable reductions in Foxp3 protein expression could also be demonstrated. Therefore, we investigated the intracellular expression of Foxp3 protein in PBMCs from HAM/TSP patients and HDs using flow cytometry with a commercially available anti-human Foxp3 antibody. Analysis of Foxp3 protein expression in subpopulations of lymphocytes from $8 \mathrm{HDs}$ revealed significant staining, as expected, in the $\mathrm{CD} 4{ }^{+} \mathrm{CD} 25^{+} \mathrm{T}$ cell subset but not the $\mathrm{CD} 4{ }^{+} \mathrm{CD} 25^{-}$or $\mathrm{CD} 4{ }^{-}$ $\mathrm{T}$ cell subsets (Figure 1, B and $\mathrm{C}$ ). A representative histogram is shown in Figure 1B. The percentage (mean \pm SD) of Foxp3-positive cells in $\mathrm{CD}^{+} \mathrm{CD} 25^{+} \mathrm{T}$ cells from 8 HDs was $25.9 \% \pm 8.23 \%$ (Figure $1 \mathrm{C}$ ). This is consistent with the hypothesis that only a subset of the $\mathrm{CD} 4^{+} \mathrm{CD} 25^{+} \mathrm{T}$ cell population may be $\mathrm{CD} 4^{+}$Tregs $(12,13)$. In contrast, the percentage (mean $\pm \mathrm{SD}$ ) of Foxp3-positive cells in $\mathrm{CD}^{+} \mathrm{CD} 25^{+} \mathrm{T}$ cells from $8 \mathrm{HAM} / \mathrm{TSP}$ patients was significantly reduced to $3.09 \% \pm 1.04 \%(P=0.0014)$ (Figure $1 \mathrm{C})$. A representative histogram is shown in Figure 1B. No difference in the protein expression levels of Foxp3 was observed in $\mathrm{CD}^{+} \mathrm{CD}^{-} 5^{-}$or $\mathrm{CD} 4^{-}$cells between HAM/TSP patients and HDs (Figure 1B). These results support the finding that foxp $3 \mathrm{mRNA}$ is reduced in $\mathrm{CD} 4^{+} \mathrm{CD} 25^{+}$ cells from HAM/TSP patients compared with HDs (Figure 1A) and continue to suggest that dysregulation of Tregs may be contribute to the pathogenesis of this disorder.

Reduced expression of regulatory cell surface marker and increased proinflammatory cytokine production in $\mathrm{CD}^{+} \mathrm{CD} 25^{+}$T cells from HAM/ TSP patients. Tregs have been characterized by their constitutive expression not only of Foxp3 but also of cell surface proteins such as CD25, CD38, CD62L, CD69, CTLA-4, and GITR (17-21, 23, $32,33)$. To determine the levels of these cell surface molecules, we investigated their expression in $\mathrm{CD} 4^{+} \mathrm{CD} 25^{+} \mathrm{T}$ cells from both HAM/TSP patients and HDs. As shown in Table 2, CD $4{ }^{+} \mathrm{CD} 25^{+} \mathrm{T}$ cells from HAM/TSP patients showed lower expression of CD38 $(P=0.0003)$, CD62L $(P=0.0374)$, CD69 $(P=0.0101)$, CTLA-4 $(P=0.0104)$, and GITR $(P=0.0010)$ molecules than those from HDs, while the expression of HLA-DR was not significantly different. We confirmed a decrease in CD45RA expression $(P=0.0112)$ and an increase in CD45RO expression $(P<0.0001)$ in $\mathrm{CD}^{+} \mathrm{CD} 25^{+} \mathrm{T}$ cells from HAM/TSP patients (Table 2 ), as had been previously reported $(34,35)$. We also investigated intracellular cytokine expression in $\mathrm{CD} 4^{+} \mathrm{CD} 25^{+} \mathrm{T}$ cells. The expression of proinflammatory cytokine such as IL-2 $(P=0.0011)$ and IFN- $\gamma(P=0.0034)$ was significantly increased in HAM/TSP patients compared with HDs, whereas there were no significant differences in expression of Th2 cytokines such as IL-4 and IL-10 (Table 2). Collectively, these results demonstrate a reduction in cell surface molecules, particularly GITR and CTLA-4, which have been associated with $\mathrm{CD} 4{ }^{+}$Tregs, on $\mathrm{HAM} / \mathrm{TSP} \mathrm{CD} 4^{+} \mathrm{CD} 25^{+}$cells (17-21). These findings are consistent with our previous observations on reduced Foxp3 expression (Figure 1).

Lack of regulatory function in $C D 4^{+} C D 25^{+} T$ cells from $H A M / T S P$ patients. While we have shown a decrease in foxp $3 \mathrm{mRNA}$ and protein expression in $\mathrm{HAM} / \mathrm{TSP} \mathrm{CD} 4{ }^{+} \mathrm{CD} 25^{+}$cells as well as other cell surface markers that characterize $\mathrm{CD}^{+}$Tregs, it remains to be determined whether this corresponds to a reduction in Treg function. To determine the effect of HAM/TSP CD $4{ }^{+} \mathrm{CD} 25^{+}$cells on $\mathrm{T}$ cell regulatory function, we performed functional CFSE proliferation assays. As shown Figure 2, HD CD $4^{+} \mathrm{CD} 25^{-} \mathrm{T}$ cells specifically proliferated upon stimulation with anti-CD3 antibody. As expected, addition of irradiated, sorted allogeneic $\mathrm{HD} \mathrm{CD} 4^{+} \mathrm{CD} 25^{+}$(which did not proliferate; data not shown) to these HD CD $4^{+} \mathrm{CD} 25^{-}-$ responding cells resulted in an inhibition of proliferation consistent with a Treg function of $\mathrm{HD} \mathrm{CD} 4^{+} \mathrm{CD} 25^{+}$cells $(14,36,37)$. In contrast, coculturing irradiated $\mathrm{HAM} / \mathrm{TSP} \mathrm{CD} 4{ }^{+} \mathrm{CD} 25^{+}$cells with $\mathrm{HD} \mathrm{CD} 4^{+} \mathrm{CD} 25^{-}$cells did not suppress the proliferative capacity of these anti-CD3-stimulated, responding $\mathrm{CD} 4^{+} \mathrm{CD} 25^{-}$cells (Figure 2). These results suggest that Treg function in $\mathrm{CD} 4^{+} \mathrm{CD} 25^{+}$cells from HAM/TSP patients is dysregulated.

HTLV-I Tax suppresses foxp3 expression. Since Foxp3 message and protein expression were significantly reduced in HAM/TSP $\mathrm{CD} 4^{+} \mathrm{CD} 25^{+}$cells relative to those from HDs, we hypothesized that the virus-encoded transactivating tax gene $(38,39)$ might be associated with this reduction. To investigate this possibility, we transfected an HTLV-I tax DNA vector known to express high levels of HTLV-I Tax protein (40) into purified $\mathrm{CD} 4^{+} \mathrm{CD} 25^{+} \mathrm{T}$ cells and $\mathrm{CD}^{+} \mathrm{CD} 25^{-} \mathrm{T}$ cells from 7 HDs using a highly efficient electroporation transfection system (greater than $70 \%$ of transfected

\section{Table 2}

Cell surface marker expression and proinflammatory cytokine production in CD4+CD25+ T cells from HAM/TSP patients and HDs

\begin{tabular}{lccccc}
\multicolumn{5}{c}{ HAM $(\boldsymbol{n}=\mathbf{6})$} & \multicolumn{2}{c}{ HDs $(\boldsymbol{n}=\mathbf{6})$} & \\
& Mean & SD & Mean & SD & $\boldsymbol{P}$ value $^{A}$ \\
CD45RA & 5.34 & 4.95 & 28.9 & 19.8 & $P=0.011$ \\
CD45R0 & 95.1 & 3.17 & 71.6 & 9.89 & $P<0.0001$ \\
CD27 & 45.9 & 22.8 & 64.1 & 8.97 & NS \\
CD28 & 88.4 & 12.5 & 53.8 & 31.8 & $P=0.0472$ \\
CD38 & 8.6 & 1.51 & 21.3 & 6.23 & $P=0.0003$ \\
HLA-DR & 36.2 & 22.9 & 15.5 & 16.4 & NS \\
CD69 & 1.87 & 1.11 & 24.5 & 19.5 & $P=0.0101$ \\
CTLA-4 & 0.13 & 0.14 & 3.83 & 5.63 & $P=0.0104$ \\
GITR & 2.58 & 3.1 & 13.2 & 5.5 & $P=0.0010$ \\
IL-4 & 2.82 & 0.89 & 2.82 & 3.26 & NS \\
IL-10 & 0.2 & 0.12 & 0.68 & 0.53 & NS \\
IL-2 & 38.7 & 21.5 & 2.9 & 1.79 & $P=0.001$ \\
INF- $\gamma$ & 17.5 & 10.3 & 2.62 & 2.61 & $P=0.0034$ \\
& & & & &
\end{tabular}

AAccording to Student's $t$ test. Data represent percentages in CD4+CD25+ cells from HAM/TSP patients and HDs. 

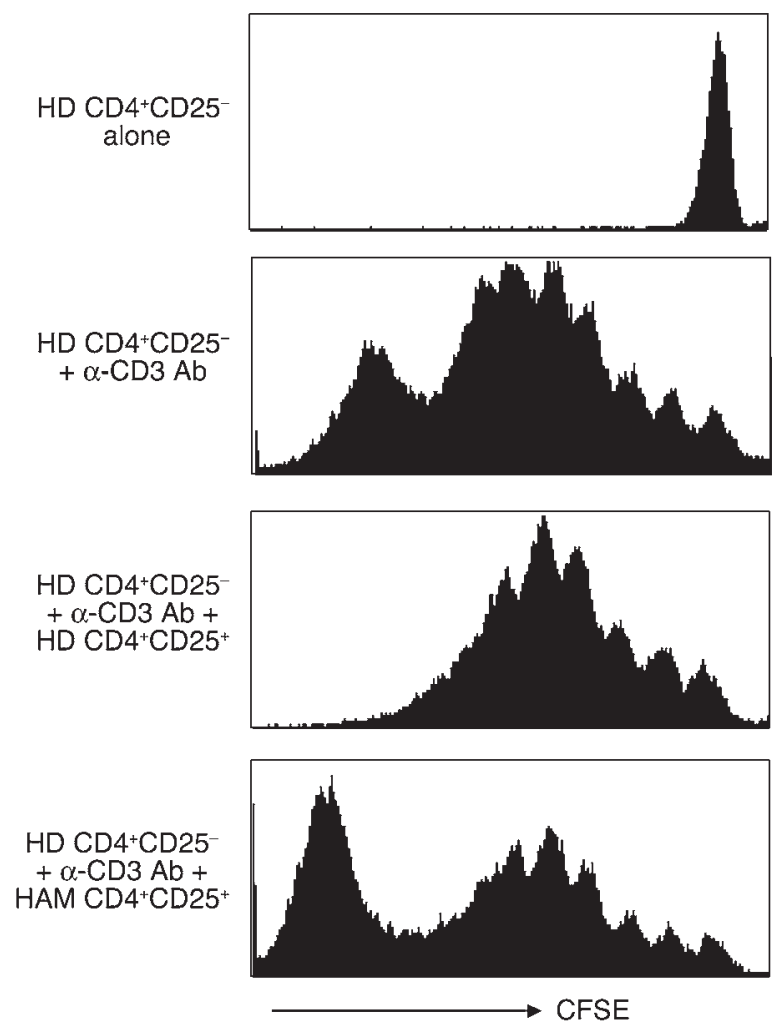

cells expressed the transgene). We measured foxp 3 mRNA expression using real-time RT-PCR before and after transfection. As shown in Figure 3, in all donors, the foxp 3 mRNA expression level in $\mathrm{CD}^{+} \mathrm{CD} 25^{+} \mathrm{T}$ cells was significantly decreased by transfection with HTLV-I tax DNA $(P=0.018)$. By contrast, there was no significant difference in the level of foxp 3 message in $\mathrm{CD}^{+} \mathrm{CD} 25^{-} \mathrm{T}$ cells before and after HTLV-I tax DNA transfection (Figure 3, A and B). When $\mathrm{CD} 4^{+} \mathrm{CD} 25^{+} \mathrm{T}$ cells from HDs were transfected with another HTLV-I gene expression vector, HTLV-I env, no change in foxp 3 mRNA expression level was observed (Figure 3B). These results support the hypothesis that the transactivating HTLV-I tax gene is associated with the reduction in foxp 3 message and protein expression observed in HAM/TSP CD $4{ }^{+} \mathrm{CD} 25^{+} \mathrm{T}$ cells.

Loss of regulatory function in $\mathrm{HTLV}$-I tax-transfected $\mathrm{HD} C D 4^{+} \mathrm{CD} 25^{+}$ $T$ cells. As we had demonstrated that HTLV-I tax significantly reduced foxp3 messenger RNA levels in HTLV-I tax-transfected $\mathrm{HD} \mathrm{CD} 4^{+} \mathrm{CD} 25^{+}$cells, it was of interest to determine whether this also corresponded to a reduction in $\mathrm{T}$ cell regulatory function in this population of cells. As shown in Figure 4 (a representative experiment using cells from 3 different HDs), $\mathrm{HD} \mathrm{CD} 4^{+} \mathrm{CD} 25^{-} \mathrm{T}$ cells alone proliferated upon stimulation with anti-CD3 antibody, while the capacity of $\mathrm{HD} \mathrm{CD} 4^{+} \mathrm{CD} 25^{+}$regulatory cells to proliferate upon this stimulus was significantly diminished. As expected, addition of $\mathrm{HD} \mathrm{CD} 4{ }^{+} \mathrm{CD} 25^{+}$to autologous $\mathrm{HD} \mathrm{CD} 4^{+} \mathrm{CD} 25^{-}-$ responding cells demonstrated an inhibition of proliferation. In contrast, coculturing of HTLV-I Tax-transfected HD CD $4^{+} \mathrm{CD} 25^{+}$ cells (which induced a reduction in foxp 3 message; Figure 3 ) with $\mathrm{HD} \mathrm{CD} 4^{+} \mathrm{CD} 25^{-}$failed to suppress the proliferation of these antiCD3-stimulated, responding $\mathrm{CD} 4^{+} \mathrm{CD} 25^{-}$cells (Figure 4). These results support the hypothesis that the reduction of levels in Foxp3 in HAM/TSP CD $4{ }^{+} \mathrm{CD} 25^{+}$cells is mediated through infec-

\section{Figure 2}

Lack of regulatory function in $\mathrm{CD} 4{ }^{+} \mathrm{CD} 25^{+} \mathrm{T}$ cells from $\mathrm{HAM} / \mathrm{TSP}$ patients. A total of $1 \times 10^{5} \mathrm{CD} 4{ }^{+}{ }^{C D 25}-\mathrm{T}$ cells/well from HDs were labeled with CFSE. They were cultured for 6 days in the culture medium in the absence or presence of $2.5 \mu \mathrm{g} / \mathrm{ml}$ anti-CD3 antibody (top 2 panels). They were also cultured for 6 days in $2.5 \mu \mathrm{g} / \mathrm{ml}$ anti-CD3 antibody added to culture medium with $1 \times 10^{5}$ irradiated allogeneic $\mathrm{CD}^{+}{ }^{+} \mathrm{CD} 25^{+} \mathrm{T}$ cells from HDs or with $1 \times 10^{5}$ irradiated CD4 ${ }^{+} \mathrm{CD} 25^{+}$ $\mathrm{T}$ cells from HAM/TSP patients (bottom 2 panels). The data indicate that regulatory function in $\mathrm{CD} 4{ }^{+} \mathrm{CD} 25^{+} \mathrm{T}$ cells from $\mathrm{HAM} / \mathrm{TSP}$ patients is reduced in comparison with that in $\mathrm{CD} 4{ }^{+} \mathrm{CD} 25^{+} \mathrm{T}$ cells from HDs. Failure of $\mathrm{CD} 4{ }^{+} \mathrm{CD} 25^{+} \mathrm{T}$ cells to suppress lymphoproliferation of activated $H D$ cells was observed in separate experiments with cells from 4 HAM/TSP patients, while suppression of activated HD cell proliferation by allogeneic HD CD4 ${ }^{+} \mathrm{CD} 25^{+} \mathrm{T}$ cells from $2 \mathrm{HDs}$ was demonstrated.

tion with HTLV-I and may result in dysregulation in Treg function of HTLV-I-infected CD $4{ }^{+} \mathrm{CD} 25^{+}$Tregs.

\section{Discussion}

Naturally arising $\mathrm{CD} 4^{+} \mathrm{CD} 25^{+}$Tregs are engaged in dominant control of self-reactive $T$ cells, contributing to the maintenance of immunological self tolerance. It has been known that foxp 3 is specifically expressed in $\mathrm{CD} 4{ }^{+} \mathrm{CD} 25^{+}$Tregs and is a key gene for the development and function of Tregs (22-24). Therefore, to test the hypothesis that HTLV-I-infected $\mathrm{CD} 4^{+} \mathrm{CD} 25^{+} \mathrm{T}$ cells may lack regulatory potential in HAM/TSP patients, we measured foxp3 gene expression quantitatively and demonstrated that Foxp 3 expression in $\mathrm{CD} 4{ }^{+} \mathrm{CD} 25^{+} \mathrm{T}$ cells of HAM/TSP patients was lower than that in cells of HDs (Figure 1). This result suggested 3 possibilities: HTLV-I has a direct inhibitory effect on Foxp3 expression; the frequency of Tregs is decreased in the $\mathrm{CD} 4{ }^{+} \mathrm{CD} 25^{+} \mathrm{T}$ cell population of HAM/ TSP patients; or HAM/TSP patients have genetically determined low expression of foxp3 gene. Although these possibilities are not mutually exclusive, to address whether HTLV-I has direct inhibitory effect on the Foxp3 expression, we tested the effect of HTLV-I tax gene transfection on foxp 3 expression in $\mathrm{CD} 4^{+} \mathrm{CD} 25^{+} \mathrm{T}$ cells from HDs. As shown in Figures 3 and 4, it was demonstrated that HTLV-I Tax had a direct inhibitory effect on Foxp3 expression and inhibited the regulatory function of $\mathrm{CD} 4^{+} \mathrm{CD} 25^{+} \mathrm{T}$ cells from $\mathrm{HDs}$. These results suggest that HTLV-I has the potential to induce the diminution of $\mathrm{CD} 4{ }^{+} \mathrm{CD} 25^{+}$Treg function through the suppression of Foxp3 expression. Moreover, this is the first report to our knowledge demonstrating the role of a specific viral gene product (HTLV-I Tax) on the expression of Foxp3 that results in inhibition of Treg function. Potentially other viruses tropic for $\mathrm{CD}^{+}$cells may have similar effects on this important function of Tregs, as has been recently reported for $\operatorname{HIV}(41,42)$.

The analysis of cell surface markers and cytokine production of $\mathrm{CD}^{+} \mathrm{CD} 25^{+} \mathrm{T}$ cells from HAM/TSP further supports the observations of reduced Foxp 3 levels. $\mathrm{CD} 4{ }^{+} \mathrm{CD} 25^{+} \mathrm{T}$ cells from HAM/TSP patients expressed lower levels of CTLA-4 and GITR molecules. CTLA-4 and GITR have also been reported to be constitutively expressed on Tregs and play a key role in normal $\mathrm{CD} 4{ }^{+} \mathrm{CD} 25^{+}$Treg function (17-21). Therefore, reduced expression of CTLA-4 and GITR on $\mathrm{CD} 4^{+} \mathrm{CD} 25^{+} \mathrm{T}$ cells of HAM/TSP patients may suggest decreased frequency of Tregs in HAM/TSP patients. However, as the CTLA- 4 expression on $\mathrm{CD}^{+} \mathrm{CD} 25^{+} \mathrm{T}$ cells is not decreased in scurfy foxp 3 mutant mice (23), this low expression of CTLA-4 on $\mathrm{CD} 4^{+} \mathrm{CD} 25^{+} \mathrm{T}$ cells of HAM/TSP patients is not caused by low 
A
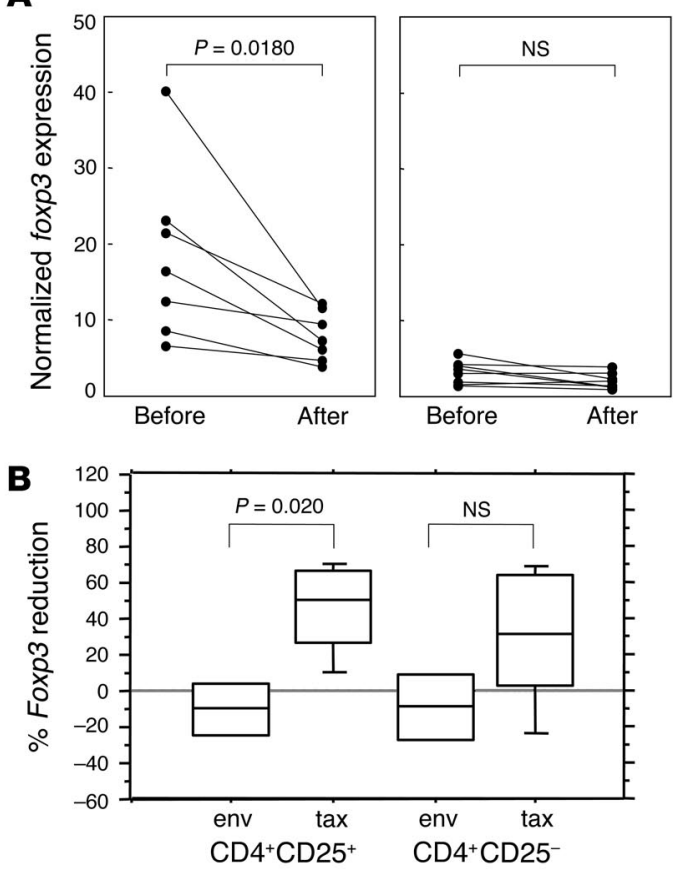

Foxp3 expression. HTLV-I may have direct suppressive effect on CTLA-4 expression. Furthermore, $\mathrm{CD}^{+} \mathrm{CD} 25^{+} \mathrm{T}$ cells from HAM/ TSP patients overproduced proinflammatory cytokines such as IL-2 and IFN- $\gamma$ (Table 2) and may contribute to the spontaneous lymphoproliferation that has been observed in such patients (43, 44). It has been reported that normal $\mathrm{CD} 4^{+} \mathrm{CD} 25^{+}$Tregs do not produce IL- 2 by themselves and lose regulatory function in the presence of exogenous IL-2 $(15,16)$. Therefore, increased production of IL-2 may further support the hypothesis that $\mathrm{CD} 4{ }^{+} \mathrm{CD} 25^{+}$ $\mathrm{T}$ cells from HAM/TSP patients have a defect in Treg function.

Activated T cells are increased in HAM/TSP patients (Table 2), and this raises the possibility that there may be a dilution of Tregs rather than a functional decrease in this population. To minimize this concern, we selected the $\mathrm{CD} 25^{+}$population from HAM/TSP patients based on gates set on CD25 high in HDs during FACS sorting. A number of studies have shown that predominantly $\mathrm{CD} 25^{\text {high }} \mathrm{T}$ cells possess regulatory functions, while $\mathrm{CD} 25^{\text {low }}$ represent activated $T$ cells $(14,37,45)$. Importantly, we have direct evidence that the introduction of HTLV-I tax downregulated foxp3 expression in $\mathrm{HD} \mathrm{CD} 4{ }^{+} \mathrm{CD} 25^{+} \mathrm{T}$ cells, while HTLV-I env did not (Figure 3B). This downregulation of foxp 3 was associated with a decrease in Treg function (Figure 4).

To demonstrate functional dysregulation, we also compared the ability of $\mathrm{CD} 4{ }^{+} \mathrm{CD} 25^{+}$Tregs isolated from HDs and from HAM/ TSP patients to suppress plate-bound CD3-activated $\mathrm{CD} 4^{+} \mathrm{CD} 25$ $\mathrm{T}$ cells from HDs. As shown in Figures 2 and 4, proliferation of plate-bound $\mathrm{CD} 3$-activated $\mathrm{CD} 4^{+} \mathrm{CD} 25^{-}$cells was diminished by $30 \%$ (Figure 4 ) with $\mathrm{HD} \mathrm{CD} 4^{+} \mathrm{CD} 25^{+} \mathrm{T}$ cells, while HAM/TSP $\mathrm{CD}^{+} \mathrm{CD} 25^{+} \mathrm{T}$ cells (Figure 2 ) or HTLV-I tax-transfected T cells (Figure 4) did not suppress $\mathrm{T}$ cell proliferation. Collectively, these data suggest defects in the function of HAM/TSP CD $4^{+} \mathrm{CD} 25^{+}$ Tregs. The suppression of activated $\mathrm{CD} 4^{+} \mathrm{CD} 25^{-} \mathrm{T}$ cells by Tregs we observed is consistent with previous reports $(12,14,16,46)$, although Baecher-Allan et al. have demonstrated inhibition of $\mathrm{CD} 4^{+} \mathrm{CD} 25^{+}$Treg function when responding $\mathrm{CD} 4^{+} \mathrm{CD} 25^{-}$cells

\section{Figure 3}

HTLV-I Tax suppresses Foxp3 expression. Purified CD4 ${ }^{+} C D 25^{+}$ $T$ cells and $C D 4{ }^{+} C D 25-T$ cells from $H D$ s were transfected with the HTLV-I tax gene $(n=7)$ or HTLV-I env gene $(n=4)$. The foxp3 mRNA expression in these $\mathrm{T}$ cell populations before and after transfection was measured by real-time RT-PCR. (A) The foxp3 mRNA expression level in $\mathrm{CD} 4{ }^{+} \mathrm{CD} 25^{+} \mathrm{T}$ cells was significantly decreased by transfection with HTLV-I tax gene $(P=0.018)$. By contrast, there was no significant decrease in foxp3 mRNA expression in CD4 ${ }^{+} \mathrm{CD} 25^{-} \mathrm{T}$ cells. (B) foxp3 mRNA expression was significantly decreased in HTLV-I taxtransfected CD4+CD25+ T cells compared with HTLV-I env-transfected CD4 ${ }^{+}$CD25 $5^{+} \mathrm{T}$ cells $(P=0.020)$. There was no significant difference between the foxp3 mRNA expression in HTLV-I tax transfected CD4 ${ }^{+}$CD25- $T$ cells and that in HTLV-I env-transfected CD4 ${ }^{+}$CD25- T cells. env, HTLV-I env gene; tax, HTLV-I tax gene.

were stimulated with high concentrations of plate-bound CD3 (46). Difference in these 2 studies could be explained by the different ratios of responding suppressor $\mathrm{T}$ cells used. In the present study, we demonstrated the suppressive function using a 1:1 ratio of $\mathrm{CD} 4^{+} \mathrm{CD} 25^{+}$Tregs to responder cells.

It has been reported that naturally present Tregs may act to hamper effective immune responses to invading pathogenic microbes $(33,47,48)$. For example, in mice infected with Friend retrovirus, it was demonstrated that $\mathrm{CD}^{+}$Tregs were increased in number and showed immunosuppressive activity. These $\mathrm{CD} 4^{+}$ Tregs had increased expression of $\mathrm{CD} 38^{+}$and $\mathrm{CD} 9^{+}(33)$. In contrast, the expression of $\mathrm{CD} 38^{+}$and $\mathrm{CD} 69^{+}$on $\mathrm{CD} 4^{+} \mathrm{CD} 25^{+} \mathrm{T}$ cells was decreased in HAM/TSP patients and did not show immuno-

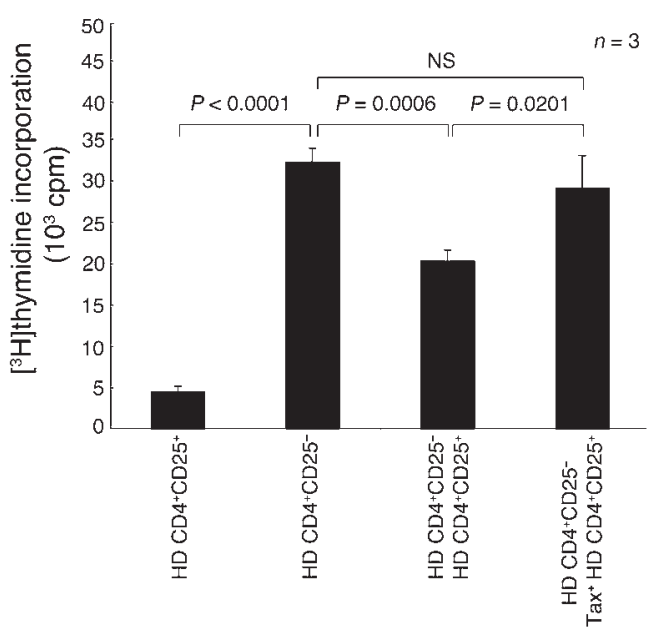

Figure 4

Loss of regulatory function in HTLV-I tax-transfected HD CD4+CD25+ T cells. CD4 ${ }^{+} \mathrm{CD} 25^{+}$or $\mathrm{CD} 4^{+} \mathrm{CD} 25^{-} \mathrm{T}$ cells from uninfected HDs were stimulated with $2.5 \mu \mathrm{g} / \mathrm{ml}$ anti-CD3 antibody and irradiated PBMCs and cultured for 4 days (HD CD25+ and HD CD25-). Furthermore, to compare the suppressive activity of $\mathrm{HD} \mathrm{CD} 4{ }^{+} \mathrm{CD} 25^{+} \mathrm{T}$ cells before and after HTLV-I tax gene transfection, CD4 ${ }^{+}$CD25- $T$ cells from HDs were stimulated with $2.5 \mu \mathrm{g} / \mathrm{ml}$ anti-CD3 antibody and irradiated PBMCs and cultured for 4 days in the presence of equal numbers of HD CD4+CD25+ T cells or HTLV-I tax-transfected HD CD4+CD25+ T cells $\left(\mathrm{Tax}^{+} \mathrm{HD}\right.$ CD25+). After culture, $\left[{ }^{3} \mathrm{H}\right]$ thymidine was added for additional 16 hours. The suppressive activity of $C D 4+C D 25^{+} T$ cells from $H D s$ was inhibited by transfection with the HTLV-I tax gene. Data represent the mean of experiments with cells from 3 HDs. 
suppressive activity. These results suggest that $\mathrm{CD}^{+} 8^{+}$and $\mathrm{CD} 69^{+}$ are also important cell surface markers that may distinguish human Tregs from effector $T$ cells, as reported previously in studies on rodents $(32,33)$.

It has been reported that microbial infection can dysregulate Tregs to suppress pathologic antimicrobial immune responses that cause tissue damage (i.e., immunopathologic response) $(49,50)$. For example, in SCID mice chronically infected with Pneumocystis carinii, transfer of T cells depleted of CD $4^{+} \mathrm{CD} 25^{+}$ Tregs elicited severe pneumonitis, whereas transfer of $\mathrm{T}$ cells not depleted of Tregs did not (49). Thus, in controlling microbial immunity, the frequency of $\mathrm{CD} 4^{+} \mathrm{CD} 25^{+}$Tregs may play an important role. However, it is not known how these $\mathrm{T}$ cells contribute to the regulation of antimicrobial immune responses. The increased expression of CD28 molecules and decreased expression of CTLA- 4 on $\mathrm{CD} 4^{+} \mathrm{CD} 25^{+} \mathrm{T}$ cells in HAM/TSP patients (shown in this study) may therefore serve to regulate this population of cells (51). CD28 and CTLA-4 share the same ligands (CD80 and CD86) on APCs, and CD28 has much lower affinity for CD80 and CD86 than CTLA-4 (52). CTLA-4 has been reported to be required for the suppressive function of Tregs. In contrast, stimulation through CD28, with concurrent TCR stimulation, abrogates suppressive function $(15,16) . \mathrm{CD}^{+} \mathrm{CD} 25^{+} \mathrm{T}$ cells have been reported to be a major reservoir of HTLV-I and to present HLA-virus peptide complexes (30). This increased expression of HTLV-I peptide/HLA complexes on $\mathrm{CD} 4^{+} \mathrm{CD} 25^{+}$ cells may increase activation of these cells by signaling through $\mathrm{CD} 28$, resulting in the loss of $\mathrm{T}$ cell regulatory/suppressive activity. Further comparative analysis of the expression of these molecules on $\mathrm{CD} 4{ }^{+} \mathrm{CD} 25^{+} \mathrm{T}$ cells between healthy individuals infected with HTLV-I and patients with HAM/TSP will be necessary to confirm these hypothesis.

In summary, it was demonstrated that in $\mathrm{CD} 4{ }^{+} \mathrm{CD} 25^{+} \mathrm{T}$ cells from HAM/TSP patients that were preferentially infected with HTLV-I, Foxp3 expression was lower than that in cells from HDs. HTLV-I Tax had a direct inhibitory effect on Foxp3 expression and inhibited the regulatory function of $\mathrm{CD} 4^{+} \mathrm{CD} 25^{+} \mathrm{T}$ cells from HDs. Furthermore, compared to $\mathrm{CD} 4{ }^{+} \mathrm{CD} 25^{+} \mathrm{T}$ cells from $\mathrm{HD}, \mathrm{CD} 4^{+} \mathrm{CD} 25^{+} \mathrm{T}$ cells from HAM/TSP patients showed lower expression of constitutive molecules of Tregs such as CD38, CD62L, CD69, CTLA-4, and GITR and overproduced proinflammatory cytokines such as IL-2 and IFN- $\gamma$. In addition, loss of function of $\mathrm{CD} 4^{+} \mathrm{CD} 25^{+} \mathrm{T}$ cells has also been reported in other autoimmune disorders such as type 1 diabetes, rheumatoid arthritis, and multiple sclerosis, a neurodegenerative disorder of unknown etiology $(37,45,53)$. The finding that autoreactive $\mathrm{T}$ cells in patients with autoimmune diseases are more easily activated $(54,55)$ than those in healthy individuals suggest that $\mathrm{CD}^{+}{ }^{+} \mathrm{CD} 25^{+}$Tregs may play a role in controlling the development of autoimmunity. A dysfunction in Tregs in HAM/TSP is consistent with the hypothesis that an autoimmune component may also contribute to the pathogenesis of HAM/TSP (reviewed in ref. 56). Although it has been well demonstrated that the removal or functional alteration of $\mathrm{CD} 4{ }^{+} \mathrm{CD} 25^{+}$Tregs from normal rodents leads to the spontaneous development of autoimmune diseases, how these cells lose their suppressive function in human disease is unknown. This study suggests the hypothesis that the direct human retrovirus infection of $\mathrm{CD} 4^{+} \mathrm{CD} 25^{+} \mathrm{T}$ cells may contribute to a dysregulation of $\mathrm{CD} 4^{+} \mathrm{CD} 25^{+}$Tregs in a human retrovirus-associated neurologic disease.

\section{Methods}

Subjects and cell preparation. The PBMCs were prepared by centrifugation over Ficoll-Hypaque gradients (BioWhittaker) from 13 HAM/TSP patients, 13 HTLV-I-seronegative HDs, and $2 \mathrm{ACs}$, and the cells were viably cryopreserved in liquid nitrogen until tested. HAM/TSP was diagnosed according to WHO guidelines (57). HTLV-I seropositivity was determined by ELISA (Abbott Laboratories), with confirmation by Western blot analysis (Genelabs Technologies Inc.). Blood samples were obtained after informed consent as part of a clinical protocol reviewed and approved by the NIH institutional review panel. $\mathrm{CD} 4^{+} \mathrm{T}$ cells were negatively selected from the PBMCs with magnetic beads (MACS CD4 ${ }^{+} \mathrm{T}$ cell isolation kit; Miltenyi Biotec) according to the manufacturer's instructions. These selected CD4 ${ }^{+}$ $\mathrm{T}$ cells were stained with anti-CD25 FITC (Caltag Laboratories) and sorted into $\mathrm{CD} 4{ }^{+} \mathrm{CD} 25^{+}$(sorted $\mathrm{CD} 25^{+}$cells were gated on high levels of expression of CD25 in HDs during FACS sorting; Supplemental Figure 1) and $\mathrm{CD} 4^{+} \mathrm{CD} 25^{-} \mathrm{T}$ cells using FACSVantage (BD).

Foxp3 expression analysis by real-time RT-PCR. Total RNA was extracted using RNeasy Mini Kit (QIAGEN) according to the manufacturer's instructions, and cDNA was synthesized from extracted RNA using TaqMan Gold RT-PCR Kit using Random Hexamer primer (Applied Biosystems). foxp3 mRNA expression was quantified by real-time PCR using ABI PRISM 7700 Sequence Detector (Applied Biosystems). Real-time RT-PCR was performed using the protocol described in our previous report (10), with some modification. Sample cDNA from 100 ng RNA was applied per well and analyzed. Samples were run in duplicate, and the mean values were used for calculation. The primer set for foxp 3 was 5 '-GGCCCTTCTCCAGGACAGA-3' and 5'-GCTGATCATGGCTGGGTTGT-3'. The probe for foxp 3 was $5^{\prime}$-FAM-ACTTCATGCATCAGCTCTCCACTGTGGATTAMRA- $3^{\prime}$. Amplification was carried out at $50^{\circ} \mathrm{C}$ for 2 minutes, $95^{\circ} \mathrm{C}$ for 10 minutes, and 45 cycles at $95^{\circ} \mathrm{C}$ for 15 seconds and $60^{\circ} \mathrm{C}$ for 1 minute in a total volume of $50 \mu \mathrm{l}$. We used the human housekeeping gene bypoxanthine ribosyl transferase (HPRT) primers and probe set (Applied Biosystems) to calculate for normalized values of foxp 3 mRNA expression. The normalized values in each sample were calculated as the relative quantity of foxp3 mRNA expression divided by the relative quantity of HPRT mRNA expression. The values were calculated by the following formula: normal-

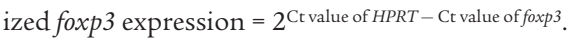

Flow cytometric analysis. PBMCs were immunostained with various combinations of the following fluorescence-conjugated antibodies: CD25 (CALTAG Laboratories), CD4, CD45RA, CD45RO, CD27, CD28, CD38, CD62L, HLA-DR, CD69, CTLA-4 (BD Biosciences - Pharmingen), and GITR (R\&D Systems). These cells were also intracellularly stained with the following antibodies: IL-2, IFN- $\gamma$, IL-4, IL-10 (BD Biosciences - Pharmingen), and Foxp3 (Abcam Inc). Flow cytometric analysis was performed on a FACSCalibur cytometer (BD Biosciences). Data processing was accomplished with CELLQuest software (BD).

Transfection. The sorted cells from HDs were harvested in a seeding condition of $1 \times 10^{6} \mathrm{cell} / \mathrm{ml}$ and were incubated for 2 hours at $37^{\circ} \mathrm{C}$ in RPMI 1640 supplemented with $10 \% \mathrm{FCS}, 100 \mu \mathrm{g} / \mathrm{ml}$ streptomycin, $100 \mathrm{U} / \mathrm{ml}$ penicillin, and $2 \mathrm{mM}$ glutamine (culture medium). The cells washed once in PBS and resuspended in the specified electroporation buffer (Nucleofector solution; Amaxa) to a final concentration of $1 \times 10^{6}$ cells $/ 100 \mu \mathrm{l}$. Then $2 \mu \mathrm{g}$ of HTLV-I env plasmid DNA or HTLV-I tax plasmid DNA (kindly provided by D. Derse, National Cancer Institute-Frederick, Frederick, Maryland, USA) were added to the cell suspension and they were transfected using $\mathrm{T}$ cell Nucleofector kit (Amaxa) according to the manufacturer's instructions. After electroporation, the cells were immediately suspended in $2 \mathrm{ml}$ of culture medium and cultured overnight at $37^{\circ} \mathrm{C}$ in a $5 \% \mathrm{CO}_{2}$ incubator.

Proliferation assay by CFSE. A total of $1 \times 10^{5} \mathrm{CD} 4^{+} \mathrm{CD} 25^{-} \mathrm{T}$ cells/well from HD were labeled with CFSE using Vybrant CFDA SE Cell Tracer Kit 
(Invitrogen Corp.) according to the manufacturer's instructions. Cells were incubated for 6 days in the culture medium with or without $2.5 \mu \mathrm{g} / \mathrm{ml}$ antiCD3 antibody in round-bottomed 96-well plates. In some cultures, $1 \times 10^{5}$ irradiated allogeneic $\mathrm{CD} 4^{+} \mathrm{CD} 25^{+} \mathrm{T}$ cells from HDs or $1 \times 10^{5}$ irradiated allogenic $\mathrm{CD} 4^{+} \mathrm{CD} 25^{+} \mathrm{T}$ cells from HAM/TSP patients were added. Cells were subjected to flow cytometric analysis.

Proliferation assay by liquid scintillation counter. For the proliferation assay of $\mathrm{T}$ cells from $\mathrm{HDs}, 1 \times 10^{4} \mathrm{CD}^{+} \mathrm{CD} 25^{+}$or $\mathrm{CD}^{+} \mathrm{CD} 25^{-} \mathrm{T}$ cells/well from HDs were cultured in $200 \mu \mathrm{l}$ culture medium (RPMI 1640 supplemented with L-glutamine, penicillin, streptomycin, and $5 \%$ human $\mathrm{AB}$ serum) in roundbottomed 96-well plates. These cell populations were stimulated with 2.5 $\mu \mathrm{g} / \mathrm{ml}$ anti-CD3 antibody (OKT-3; BD) in the presence of $5 \times 10^{4}$ irradiated PBMCs. After 4 days culture, $1 \mu \mathrm{Ci}$ tritium thymidine $\left(\left[{ }^{3} \mathrm{H}\right] \mathrm{TdR}\right) /$ well was added for additional 16 hours. A liquid scintillation counter was used to measure proliferation. Furthermore, to compare the suppressive effect on the cell proliferation between $\mathrm{CD} 4{ }^{+} \mathrm{CD} 25^{+} \mathrm{T}$ cells and HTLV-I tax gene transfected $\mathrm{CD}^{+} \mathrm{CD} 25^{+} \mathrm{T}$ cells, $1 \times 10^{3} \mathrm{CD} 4^{+} \mathrm{CD} 25^{-} \mathrm{T}$ cells/well from $\mathrm{HD}$ were stimulated with $2.5 \mu \mathrm{g} / \mathrm{ml}$ anti-CD3 antibody (OKT-3) in the presence of $5 \times 10^{4}$ irradiated PBMCs, then cocultured with $1 \times 10^{4} \mathrm{CD} 4^{+} \mathrm{CD} 25^{+}$ $\mathrm{T}$ cells/well or with $1 \times 10^{4} \mathrm{HTLV}$-I tax-transfected $\mathrm{CD} 4^{+} \mathrm{CD} 25^{+} \mathrm{T}$ cells/ well. After 4 days culture, $1 \mu \mathrm{Ci}\left[{ }^{3} \mathrm{H}\right] \mathrm{TdR} /$ well was added for additional 16 hours. A liquid scintillation counter was used to measure proliferation.

Statistical analysis. Student's $t$ tests were used for the significance of data comparison.

Received for publication November 16, 2004, and accepted in revised form February 8, 2005.

Address correspondence to: Steven Jacobson, NIH/NINDS/ NIB Building 10, Room 5B-16, Bethesda, Maryland 20892, USA. Phone: (301) 496-0519; Fax: (301) 402-0373; E-mail: jacobsons@ninds.nih.gov.
1. Osame, M., et al. 1986. HTLV-I associated myelopathy, a new clinical entity [letter]. Lancet. 1:1031-1032.

2. Gessain, A., et al. 1985. Antibodies to human Tlymphotropic virus type-I in patients with tropical spastic paraparesis. Lancet. 2:407-410.

3. Kaplan, J.E., et al. 1990. The risk of development of HTLV-I-associated myelopathy/tropical spastic paraparesis among persons infected with HTLV-I. J. Acquir. Immune. Defic. Syndr. 3:1096-1101.

4. Nakagawa, M., et al. 1995. HTLV-I-associated myelopathy: analysis of 213 patients based on clinical features and laboratory findings. J. Neurovirol. 1:50-61.

5. Uchiyama, T. 1997. Human T cell leukemia virus type I (HTLV-I) and human diseases. Annu. Rev. Immunol. 15:15-37.

6. Nagai, M., Yamano, Y., Brennan, M.B., Mora, C.A., and Jacobson, S. 2001. Increased HTLV-I proviral load and preferential expansion of HTLV-I Taxspecific CD8+ T cells in cerebrospinal fluid from patients with HAM/TSP. Ann. Neurol. 50:807-812.

7. Jacobson, S. 2002. Immunopathogenesis of human T cell lymphotropic virus type I-associated neurologic disease. J. Infect. Dis. 186(Suppl. 2):187-192.

8. Osame, M. 2002. Pathological mechanisms of human T-cell lymphotropic virus type I-associated myelopathy (HAM/TSP). J. Neurovirol. 8:359-364.

9. Jacobson, S., Shida, H., McFarlin, D.E., Fauci, A.S., and Koenig, S. 1990. Circulating CD8+ cytotoxic T lymphocytes specific for HTLV-I pX in patients with HTLV-I associated neurological disease. Nature. 348:245-248.

10. Yamano, Y., et al. 2002. Correlation of human T-cell lymphotropic virus type 1 (HTLV-1) mRNA with proviral DNA load, virus-specific CD8(+) T cells, and disease severity in HTLV-1-associated myelopathy (HAM/TSP). Blood. 99:88-94.

11. Izumo, S., et al. 1989. The neuropathology of HTLV-I associated myelopathy in Japan: report of an autopsy case and review of the literature. In HTLV-I and the nervous system. G.C. Roman, J.C. Vernant, and M. Osame, editors. Alan R. Liss. New York, New York, USA. 261-267.

12. Sakaguchi, S., et al. 2001. Immunologic tolerance maintained by CD25+ CD4+ regulatory T cells: their common role in controlling autoimmunity, tumor immunity, and transplantation tolerance. Immunol. Rev. 182:18-32.

13. Shevach, E.M. 2002. CD4+ CD25+ suppressor T cells: more questions than answers. Nat. Rev. Immunol. 2:389-400.

14. Baecher-Allan, C., Brown, J.A., Freeman, G.J., and Hafler, D.A. 2001. CD4+CD25high regulatory cells in human peripheral blood. J. Immunol. 167:1245-1253.
15. Takahashi, T., et al. 1998. Immunologic self-tolerance maintained by $\mathrm{CD} 25+\mathrm{CD} 4+$ naturally anergic and suppressive T cells: induction of autoimmune disease by breaking their anergic/suppressive state. Int. Immunol. 10:1969-1980.

16. Thornton, A.M., and Shevach, E.M. 1998. CD4+CD25+ immunoregulatory T cells suppress polyclonal $\mathrm{T}$ cell activation in vitro by inhibiting interleukin 2 production. J. Exp. Med. 188:287-296.

17. Shimizu, J., Yamazaki, S., Takahashi, T., Ishida, Y., and Sakaguchi, S. 2002. Stimulation of CD25(+)CD4(+) regulatory T cells through GITR breaks immunological self-tolerance. Nat. Immunol. 3:135-142.

18. McHugh, R.S., et al. 2002. CD4(+)CD25(+) immunoregulatory $\mathrm{T}$ cells: gene expression analysis reveals a functional role for the glucocorticoidinduced TNF receptor. Immunity. 16:311-323.

19. Read, S., Malmstrom, V., and Powrie, F. 2000. Cytotoxic T lymphocyte-associated antigen 4 plays an essential role in the function of CD25(+)CD4(+) regulatory cells that control intestinal inflammation. J. Exp. Med. 192:295-302.

20. Salomon, B., et al. 2000. B7/CD28 costimulation is essential for the homeostasis of the CD4+CD25+ immunoregulatory $\mathrm{T}$ cells that control autoimmune diabetes. Immunity. 12:431-440.

21. Takahashi, T., et al. 2000. Immunologic self-tolerance maintained by $\mathrm{CD} 25(+) \mathrm{CD} 4(+)$ regulatory $\mathrm{T}$ cells constitutively expressing cytotoxic $\mathrm{T}$ lymphocyte-associated antigen 4. J. Exp. Med. 192:303-310.

22. Hori, S., Nomura, T., and Sakaguchi, S. 2003. Control of regulatory $\mathrm{T}$ cell development by the transcription factor Foxp3. Science. 299:1057-1061.

23. Khattri, R., Cox, T., Yasayko, S.A., and Ramsdell, F. 2003. An essential role for Scurfin in CD4+CD25+ T regulatory cells. Nat. Immunol. 4:337-342.

24. Fontenot, J.D., Gavin, M.A., and Rudensky, A.Y. 2003. Foxp3 programs the development and function of CD4+CD25+ regulatory T cells. Nat. Immunol. 4:330-336.

25. Lyon, M.F., Peters, J., Glenister, P.H., Ball, S., and Wright, E. 1990. The scurfy mouse mutant has previously unrecognized hematological abnormalities and resembles Wiskott-Aldrich syndrome. Proc. Natl. Acad. Sci. U. S. A. 87:2433-2437.

26. Kanangat, S., et al. 1996. Disease in the scurfy (sf) mouse is associated with overexpression of cytokine genes. Eur. J. Immunol. 26:161-165.

27. Clark, L.B., et al. 1999. Cellular and molecular characterization of the scurfy mouse mutant. J. Immunol. 162:2546-2554.

28. Tivol, E.A., et al. 1995. Loss of CTLA-4 leads to massive lymphoproliferation and fatal multiorgan tissue destruction, revealing a critical negative regulatory role of CTLA-4. Immunity. 3:541-547.
29. Waterhouse, P., et al. 1995. Lymphoproliferative disorders with early lethality in mice deficient in Ctla-4. Science. 270:985-988.

30. Yamano, Y., et al. 2004. Increased expression of human T lymphocyte virus type I (HTLV-I) Tax1119 peptide-human histocompatibility leukocyte antigen $A^{*} 201$ complexes on CD4+ CD25+ T cells detected by peptide-specific, major histocompatibility complex-restricted antibodies in patients with HTLV-I-associated neurologic disease. J. Exp. Med. 199:1367-1377.

31. Walker, M.R., et al. 2003. Induction of FoxP3 and acquisition of $\mathrm{T}$ regulatory activity by stimulated human CD4+CD25- T cells. J. Clin. Invest. 112:1437-1443. doi:10.1172/JCI200319441.

32. Read, S., et al. 1998. CD38+ CD45RB(low) CD4+ T cells: a population of $\mathrm{T}$ cells with immune regulatory activities in vitro. Eur. J. Immunol. 28:3435-3447.

33. Iwashiro, M., et al. 2001. Immunosuppression by $\mathrm{CD} 4+$ regulatory $\mathrm{T}$ cells induced by chronic retroviral infection. Proc. Natl. Acad. Sci. U. S. A. 98:9226-9230.

34. Richardson, J.H., Edwards, A.J., Cruickshank, J.K., Rudge, P., and Dalgleish, A.G. 1990. In vivo cellular tropism of human T-cell leukemia virus type 1. J. Virol. 64:5682-5687.

35. Okayama, A., et al. 1997. Increased expression of interleukin-2 receptor alpha on peripheral blood mononuclear cells in HTLV-I tax/rex mRNA-positive asymptomatic carriers. J. Acquir. Immune Defic. Syndr. Hum. Retrovirol. 15:70-75.

36. Baecher-Allan, C., Viglietta, V., and Hafler, D.A. 2004. Human CD 4+CD25+ regulatory T cells. Semin. Immunol. 16:89-98.

37. Viglietta, V., Baecher-Allan, C., Weiner, H.L., and Hafler, D.A. 2004. Loss of functional suppression by $\mathrm{CD} 4+\mathrm{CD} 25+$ regulatory $\mathrm{T}$ cells in patients with multiple sclerosis. J. Exp. Med. 199:971-979.

38. Fujisawa, J., Toita, M., Yoshimura, T., and Yoshida, M. 1991. The indirect association of human T-cell leukemia virus tax protein with DNA results in transcriptional activation. J. Virol. 65:4525-4528.

39. Duyao, M.P., et al. 1992. Transactivation of the c-myc promoter by human $\mathrm{T}$ cell leukemia virus type 1 tax is mediated by NF kappa B. J. Biol. Chem. 267:16288-16291.

40. Nicot, C., et al. 2004. HTLV-1-encoded p30II is a post-transcriptional negative regulator of viral replication. Nat. Med. 10:197-201.

41. Weiss, L., et al. 2004. Human immunodeficiency virus-driven expansion of CD4+CD25+ regulatory $\mathrm{T}$ cells which suppress HIV-specific CD4 T-cell responses in HIV-infected patients. Blood. 104:3249-3256.

42. Baecher-Allan, C., and Hafler, D.A. 2004. Suppressor T cells in human diseases. J. Exp. Med. 200:273-276. 
43. Itoyama, Y., et al. 1988. Spontaneous proliferation of peripheral blood lymphocytes increased in patients with HTLV-I-associated myelopathy. Neurology. 38:1302-1307.

44. Sakai, J.A., Nagai, M., Brennan, M.B., Mora, C.A., and Jacobson, S. 2001. In vitro spontaneous lymphoproliferation in patients with human T-cell lymphotropic virus type I-associated neurologic disease: predominant expansion of CD8+ T cells. Blood. 98:1506-1511.

45. Lindley, S., et al. 2005. Defective suppressor function in CD4+CD25+ T-cells from patients with type 1 diabetes. Diabetes. 54:92-99.

46. Baecher-Allan, C., Viglietta, V., and Hafler, D.A. 2002. Inhibition of human CD4(+)CD25(+high) regulatory T cell function. J. Immunol. 169:6210-6217.

47. Belkaid, Y., Piccirillo, C.A., Mendez, S., Shevach, E.M., and Sacks, D.L. 2002. CD4+CD25+ regulatory $\mathrm{T}$ cells control Leishmania major persistence and immunity. Nature. 420:502-507.

48. Aseffa, A., et al. 2002. The early IL-4 response to
Leishmania major and the resulting Th2 cell maturation steering progressive disease in BALB/C mice are subject to the control of regulatory CD4+CD25+ T cells. J. Immunol. 169:3232-3241.

49. Hori, S., Carvalho, T.L., and Demengeot, J. 2002. $\mathrm{CD} 25+\mathrm{CD} 4+$ regulatory $\mathrm{T}$ cells suppress CD4+ $\mathrm{T}$ cell-mediated pulmonary hyperinflammation driven by Pneumocystis carinii in immunodeficient mice. Eur. J. Immunol. 32:1282-1291.

50. Singh, B., et al. 2001. Control of intestinal inflammation by regulatory $\mathrm{T}$ cells. Immunol. Rev. 182:190-200.

51. Sakaguchi, S. 2004. Naturally arising CD4+ regulatory $\mathrm{T}$ cells for immunologic self-tolerance and negative control of immune responses. Annu. Rev. Immunol. 22:531-562.

52. Salomon, B., and Bluestone, J.A. 2001. Complexities of CD28/B7: CTLA-4 costimulatory pathways in autoimmunity and transplantation. Annu. Rev. Immunol. 19:225-252.

53. Ehrenstein, M.R., et al. 2004. Compromised func- tion of regulatory $\mathrm{T}$ cells in rheumatoid arthritis and reversal by anti-TNFalpha therapy. J. Exp. Med. 200:277-285.

54. Viglietta, V., Kent, S.C., Orban, T., and Hafler, D.A. 2002. GAD65-reactive T cells are activated in patients with autoimmune type 1 a diabetes. J. Clin. Invest. 109:895-903. doi:10.1172/JCI200214114.

55. Scholz, C., Patton, K.T., Anderson, D.E., Freeman, G.J., and Hafler, D.A. 1998. Expansion of autoreactive $\mathrm{T}$ cells in multiple sclerosis is independent of exogenous B7 costimulation. J. Immunol. 160:1532-1538.

56. Hollsberg, P., and Hafler, D.A. 1993. Seminars in medicine of the Beth Israel Hospital, Boston. Pathogenesis of diseases induced by human lymphotropic virus type I infection. N. Engl. J. Med. 328:1173-1182.

57. Osame, M. 1990. Review of WHO Kagoshima meeting and diagnostic guidelines for HAM/TSP. In Human retrovirology HTLV. W. Blattner, editor. Raven Press. New York, New York, USA. 191-197. 